\title{
Terremotos y Microbiota
}

\author{
WALTER LEDERMANN D.
}

Discrepamos de la creencia generalizada que asocia a catástrofes naturales la generación de epidemias y que, ante el devastador terremoto que se abatió sobre gran parte de nuestra nación, vuelve a manifestarse en temerosas voces de advertencia. No estamos solos en nuestra opinión, pues ya en el 2004 la Organización Panamericana de Salud afirmaba que "las epidemias no ocurren espontáneamente después de un desastre y los cadáveres no conducen a brotes de enfermedades"1. Las nueve o diez pandemias de cólera (según cómo se cuenten), la peste negra que despobló la Europa medieval, la aparición y diseminación mundial del SIDA y las perpetuas amenazas del virus influenza, con sus cepas aviares y porcinas, no han tenido su génesis en relación a cambios formidables de la naturaleza, sino a imprevisibles mutaciones de los microbios, diminutos y caprichosos seres que evolucionan ignorándonos por completo, aunque nuestro humano ego se satisface pensando que lo hacen para fastidiarnos. Y así, paradojalmente, mientras se esperaban grandes brotes de infecciones entéricas en las zonas afectadas por el sismo, hacía aparición uno por norovirus en el norte del país, respetado por el terremoto, alcanzando varios miles de casos y acompañándose, por añadidura, de algunas amenazas de cólera.

A estas alturas de la página, el lector ya habrá fruncido el ceño, sorprendido. Más, no tema : por supuesto -y está más que registrado y demostrado- las catástrofes naturales pueden favorecer la aparición de infecciones en brotes más o menos grandes, siempre y cuando el fenómeno revista características especiales, proclives a generar grandes hacinamientos en campamentos de damnificados, facilitando así la diseminación de enfermedades contagiosas propias de la estación. Estas infecciones se acrecientan por sólo uno de los tres factores clásicos a considerar en su génesis y desarrollo, definidos como el agente, el huésped y el medio ambiente.

Para analizarlos de uno en uno, preguntémonos primero si altera decisivamente un cataclismo la flora microbiana de la región. En el caso reciente, diríamos que no. El terremoto sacudió, removió y hasta elevó algunas tierras, pero es muy dudoso que pudiera cambiar la distribución de las bacterias telúricas con potencial patógeno, como el Bacillus anthracis, Clostridium tetani, Clostridium botulinum y el grupo de los Clostridium de la gangrena. Si ellas tuvieran sus esporas en las profundidades de la tierra, sería posible que una sacudida las trajera a la superficie, constituyéndolas en una nueva amenaza para los heridos, pero no es así, pues residen normalmente a ras del suelo, de manera que su distribución y su amenaza no variarán, es decir, no emergerán a terrenos donde nunca antes se vieron. Por último, si el terremoto llegara a sacar a luz bacterias escondidas, recordemos que las mencionadas tienen escasa capacidad de diseminación y mal pudieran generar grandes brotes: la vacunación antitetánica en Chile ha sido muy efectiva, el sismo dejó relativamente pocos heridos susceptibles a gangrena, y el botulismo y el carbunco son fáciles de detectar y de contener.

Podríamos imaginar que el maremoto, que nos resistimos a llamar con el siútico término tsunami, trajera a tierra patógenos marinos, como algunos dinoflagelados y vibriones capaces de generar masivas intoxicaciones, pero

Correspondencia a:

Walter Ledermann

E-mail: oncemayor@gmail.com 
éstos se multiplican en especies comestibles que perecen fuera del agua, de manera que sólo causarían brotes pequeños y autolimitados.

Continuemos nuestro análisis con el huésped. Éste fue quien sufrió la mayor alteración, no en su contextura, salvo las infortunadas víctimas fatales y heridos, sino "en sus circunstancias", en esa densa maraña de envolturas que se llama, malamente, civilización : esa terrible dependencia de suministros ajenos, creada por necesidades que el desarrollo tecnológico ha ido creando, entre las que destacan agua potable, combustibles, electricidad y, muy especialmente para el caso que nos ocupa, los alimentos preparados por la industria, ya sea al natural, congelados o desecados, y suministrados en envases estériles. Aquí es donde se pueden generar brotes de enteritis por Salmonella, Shigella, Listeria, virus redondos y otras especies de menor renombre, brotes que para su iniciación requieren la presencia de un portador, porque son bacterias que emergerían del hombre y no de la tierra sacudida.

Este requisito de la pre-existencia, por ser tan obvio, suele olvidarse y pareciera que volvemos a las creencias del medioevo, época en que la mayoría de la población creía en la generación espontánea, afirmando que los ratones nacían de la basura. A guisa de ejemplo, supongamos que, en un país pobrísimo y subdesarrollado, un terremoto como el nuestro reuniera tres mil personas en un campamento de refugiados : no podría generarse un brote de meningitis meningocóccica, ni aunque estuviera situado en el "cinturón de la meningitis" africano, sino existiera al menos un portador de Neisseria meningitidis entre ellos, de la misma manera que un maremoto en el sur de Chile, que removiera tierras y aguas hasta generar vastos pantanos, jamás podría producir malaria, pues ni estaría el plasmodio ni el clima favorable para el desarrollo de los Anopheles.

Por desgracia, en Chile muchos portamos transitoriamente patógenos entéricos, que podrían rápidamente causar brotes por la vía fecal-oral. ¿Cómo preparar mamaderas asépticas, cuando la madre no tiene agua ni jabón para lavarse las manos, ni hay agua potable para diluir la leche en polvo, ni puede hervir- se sin combustibles? Y ésto, si dispusiera de fórmulas en polvo y hubiera agua de alguna clase. Pero, en la medida en que ellas y los otros suministros se recuperaran, los brotes serían rápidamente abortados porque nuestra población, en materia médica y sólo en ella, es disciplinada y obediente, acatando las normas sanitarias ministeriales, y por eso el cólera no prosperó cuando, como don Diego de Almagro, pretendió invadirnos desde Perú.

Esta cultura médica es la buena huella que dejó el antiguo Servicio Nacional de Salud, diseñado con elementos que parecían salidos de órdenes militares y monásticas, y tan bien montado y regulado, que se resiste a morir y permanece en espíritu bajo el sistema actual, descentralizado y normado por un Ministerio paternal. Si usted le ordena al chileno que baje por la puerta trasera del microbús o que respete un "ceda el paso" o "no virar derecha", no lo hará, pues al hacerlo se sentiría ingenuo, gil, pero si le dice que debe vacunarse, pues se vacuna, y si la mamá debe hervir el agua para la mamadera, seguro que la hierve.

Por último, analizando el tercer elemento clásico de la cadena epidemiológica, que es el medio ambiente, sus cambios geológicos, por mucho que quieran exagerarlos algunos expertos, diciéndonos que tal ciudad se ha movido un par de centímetros o que en tal zona la costa se elevó un metro, y por mucho que sean dolorosos para la población que ha quedado con las casas en el suelo, no bastan para cambiar ni al hombre ni a la microbiota. Como decía un escritor, cuyo nombre no recordamos, "la tierra permanece" y el mayor cambio ha sido en nuestro humano orgullo, que en el caso de quien escribe saldrá más lastimado aun si en el lapso que va desde la escritura hasta la distribución de la revista se produce una gran epidemia, probando lo que siempre hemos sostenido: que las bacterias, como los duendes, tienen un espíritu burlón.

\section{Referencia}

1. Organización Panamericana de la Salud (OPS). Washington, D.C., 23 de septiembre de 2004. http://www. paho.org/Spanish/DD/PIN/ps040923.htm 